institution. To its initiative and labours Dublin owes its beautiful Botanic Gardens at Glasnevin; its Museum of Art and Natural Science; its National Gallery and School of Art; its National Library; and its College of Science now amalgamated with the National University. The Irish Fishery Department is largely due to its initiative and early support. Its great agricultural shows and horse shows are known over the world.

More recently, the Irish Radium Institute came into existence as one branch of the Society's beneficent work. Its fine pioneer work in advancing radiotherapy, mainly due to the late Dr. Walter Stevenson, is widely known. The functions of this Institute extend to all parts of Ireland.

The support of science, pure and applied, in all its branches has been one of the Society's principal functions in recent years. Its Transactions and Proceedings include some of the most important writings of Fitzgerald, Stoney, Preston, Trouton, among others. The Society supports a liberal fund for the prosecution of research by the purchase of scientific instruments which are supplied on loan to the investigator, or by money grants when a hopeful investigation is involved. In its great hall, seating 1600 persons, scientific lectures suited to a youthful audience or, again, to an audience of adults are delivered annually by recognised scientific authorities. Still more advanced lectures and demonstrations are delivered periodically in a smaller apartment.

From remote times the Society has promoted the fine arts, as already mentioned; and offers to young artists annually a valuable prize upon the result of competitive work. The prize is of sufficient value to enable the winner to go abroad for the study of art, if he so desires. Nor has the cultivation of music been neglected. Throughout each session eminent musicians perform for the benefit of the members and of the general public.

The membership of the Society to-day numbers 9000 , and a long waiting list exists. The great educational value of its membership is recognised by all.

In the celebration of its two-hundredth birthday, every effort will be made to recall its earlier history, as well as to show by contrast the advance between then and now. Early scientific instruments of historic value will be shown. Recent instruments for research devised by members of the Society will be on view. Works of art from Irish painters or sculptors which have arisen out of the Art School long ago established by the Society will be brought together. A period ball on June 26 will close the celebrations. In this, efforts to reproduce the costumes of the past will be encouraged.

June 23 is the opening day. A conversazione, and reception by the president, will be held on the evening of that day.

\section{The North Sea Earthquake.}

I ATER reports on the North Sea earthquake of June 7 add little, if anything, to our knowledge of its distribution. Several of the cracks in the Chapter House of Lincoln Cathedral were found to be widened, and the shock was felt so far to the south as Paris. The former city lies within the area of slight damage as previously traced, the latter within the boundary of the disturbed area. The course of that boundary towards the east and north remains uncertain, in the absence of records from western Germany and Denmark.

An unusual feature of the earthquake is the great extent of the sound-area. In Great Britain, the sound was heard at several places not more than fifty miles within the boundary of the disturbed area. The double nature of the shock was also observed over a wide area, and even at places so near the boundary as Elgin and Bristol.

It is remarkable that some of the earthquakes most widely felt in Britain should be of submarine origin. The earthquake of 1852-the only one felt in all four divisions of the British Isles-disturbed an area of not less than 56,000 sq. miles. The exact position of the epicentre is unknown, but it was probably submarine and not far from the coast of Ireland. The shock so generally felt in eastern Scotland four years ago was connected with a centre to the west of the Norwegian coast. A centre lying a few miles east of Jersey has been responsible for several shocks felt over the south of England and even in London. The disturbed areas of the Jersey earthquakes of 1878 and 1889 contained about 68,000 sq. miles, while that of the earthquake of 1926 cannot have been much less.

So far as we know, the focus of the recent North Sea earthquake has not been in action for several centuries. The injury to the Chapter House at Lincoln suggests, however, that a strong earthquake in the year 1185 may have been connected with the same centre. The shock is briefly described in several monastic and other chronicles. According to Holinshed ("Chronicles", vol. 2, pp. 188-189), "On the mondaie in the weeke before Easter, chanced a sore earthquake through all the parts of this land, such a one as the like had not beene heard of in England sithens the beginning of the world. For stones that laie couched fast in the earth, were remooued out of their places, stone houses were overthrowne, and the great church of Lincolne was rent from the top downwards.'

\section{Davison.}

\section{University and Educational Intelligence.}

CAMbridge.-Dr. S. Goldstein, of St. John's College, and Mr. J. M. Whittaker, of Pembroke College, have been appointed University lecturers in the Faculty of Mathematics.

Dr. N. J. J. M. Needham, of Gonville and Caius College, has been reappointed University demonstrator in bioehemistry.

The Appointments Committee of the Faculty of Biology ' $\mathrm{B}$ ' invite candidates for the post of University demonstrator in experimental psychology to send in their names to Prof. Bartlett (at the Psychological Laboratory), together with such evidence of their qualifications as they think fit, not later than Oct. 1, 1931. An appointment will be made early in the Michaelmas Term 1931. The salary of the demonstrator will be $£ 160$ per annum.

The Benn W. Levy research studentship in biochemistry is vacant. Applications for its tenure should be addressed to Sir F. G. Hopkins at the School of Biochemistry, before July 1.

The title of Professor Emeritus has been conferred on Sir R. H. Biffen upon his retirement from the professorship of agricultural botany.

The General Board has been authorised to reappoint Sir Horace Lamb, of Trinity College, to the Rayleigh lectureship in mathematics.

The Vice-Chancellor; Prof. Seward, Master of Downing College; T. Knox-Shaw, of Sidney Sussex ; Prof. Debenham, C. F. Cooper, of Trinity Hall; Sir E. H. Young, of Trinity College; J. M. Wordie, of St. John's College ; and R. E. Priestley, of Clare College, have been appointed a Syndicate to prepare a scheme for the erection of a building for the Scott Polar Research Institute.

Prof. G. H. Hardy, Savilian professor of geometry

No. 3216, VoL. 127] 
in the University of Oxford, has been elected to the Sadleirian professorship of pure mathematics, in succession to Prof. E. W. Hobson, who has resigned.

Appicications are invited by the Director of Agriculture, Punjab, for the Maynard Ganga Ram Prize of the value of 3000 rupees, which will be awarded for a discovery, or an invention, or a new practical method tending to increase agrieultural production in the Punjab on a paying basis. Applications must reach the Director of Agriculture, Punjab, Lahore, by, at latest, Dec. 31, 1932.

The Council of the Institution of Electrical Engineers offers a Ferranti Scholarship of the annual value of $£ 250$ and tenable for two years, for wholetime research or post-graduate work. Candidates must be less than twenty-six years of age, and nominations must be received by Aug. 15. Particulars of these scholarships can be obtained from the Secretary of the Institution, Savoy Place, London, W.C.2.

THE following have been appointed to Commonwealth Fund fellowships tenable by candidates from the British Dominions: Mr. Ernest Beaglehole (Now Zealand and London) to Yale University, in psychology; Mr. N. S. Grace (Saskatchewan and London) to the University of California, in chemistry; Mr. Bernard Notcutt (Stellenbosch and Oxford) to the University of California, in philosophy. The following have been appointed to fellowships tenable by candidates holding appointments in Government service overseas: Mr. T'. G. G. Beck (Public Works Department, Government of Now Zealand) to the University of California, in civil engineering; $\mathrm{Mr}$. B. J. Dippenaar (Department of Agriculture, Union of South Africa) to the University of Wisconsin, in agriculture; Mr. A. R. B. Edgecombe (Public Works Department, Government of India) to the University of California, in electrical engineering; Mr. H. $\mathrm{R}$. Knowles (Department of Agriculture, Union of South Africa) to the University of Wisconsin, in agriculture ; Mr. E. H. Samuel (Civil Service, Government of Palestine) to Columbia University, in economics; Mr. George Stark (Native Development Department, Government of Southern Rhodesia) to the University of North Carolina, in education.

Is the Report for the year 1929-30 of the University of Leeds, prominence is given to the development, actual and prospective, of the Cniversity's residential accommodation for students. Devonshire Hall, begun in 1928, already accommodates 140 men and is one of the largest hostels in a modern university. The plans of the building make provision for further expansion, but the extent to which this shall take place will depend not only on funds becoming available but also on the solution of the problem of how many students can appropriately be associated within a single hostel. Another important addition to the University's buildings is the mining block, finished during the summer. Here accommodation is roserved for members of the scientific staff of the Department of Scientific and Industrial Rescarch engaged on a chemical and physical survey of the coal resources of West Yorkshire, which is part of a survey of the coal resources of Great Britain being carried out by the Government. Statistical tables annexed to the report show a substantial increase in the number of day students, both full-time (from 1385 to 1434 ) and parttime (from 144 to 219). Evening classes, chiefly textile and fuel (industrial), show a falling off from 223 to 144 .

No. 3216, VoL. 127]

\section{Birthdays and Research Centres.}

June 20, 186I.-Prof. Sir F. G. Hopkins, Pres. R.S., Sir William Dunn professor of biochemistry in the University of Cambridge.

My department is engaged upon a variety of biochemical problems, but of late years we have given the most attention to a study of the catalytic control of biochemical reactions and especially of oxidations in the living cell. We are endeavouring to apply such studies widely in the biological field; not to mammalian tissues alone, but to cvery form of living cell. I think that very significant knowledge can be won by studying the metabolism of living organisms; not a little has come to light as the result of work by my colleagues in Cambridge.

I have myself returned lately to a study of the functions of glutathione in tissue respiration, and find that, in some tissues at any rate, it plays a real part in the organisation of events. I am also following up certain lines of vitamin research.

June 22, I864.-Sir Danlel Hall, K.C.B., F.R.S., Chief Scientific Adviser, Ministry of Agriculture and Fisheries, and Director of John Innes Horticultural Institution.

So far as my personal work is concerned, I am endeavouring to clear up certain points in the taxonomy of tulip species, which has taken on a new aspect since the discovery of polyploidy in the genus by the late Mr. W. C. F. Newton. Tulips present various other problems of great significance in general botanical theory, but they can be resolved only by breeding experiments. Since six years are required on the average to bring a tulip seed to the flowering stage and two or threo generations are necessary, I am trusting to some successor eventually to work out the material I am initiating.

Herein lies the great value of a research foundation like the John Innes Horticultural Institution ; it can embark with some confidence upon a scheme of work that may require a long term of years for its completion. The genetics of fruit trees affords a case in point; a generation is rarely less than seven years with apples, plums, and chorries, and although Mr. Crane has already obtained results of prime import. ance, they still open up fresh vistas of more extended work.

Considering the magnitude of British interests in the tropics and the fact that all progress in the improvement of tropical crops like copra, rubber, tea, coffee, etc., depends upon genetical work, it is lamentable to see how little recognition the subject still receives either in our universities at home or in our experimental stations overseas.

June 22, I887.- Prof. JULIAN HUXLEY, honorary lecturer in zoology at King's College, London.

I am myself especially interested in various lines of work bearing directly or indirectly upon the relation of hereditary constitution to adult characters : such problems as the effects of individual genes during development, the study of changes in relative size of organs with growth, and the systematic study of gene-expression under different environmental conditions.

I am also much interested in the species problem, and wish that a concerted attack could be directed upon it by a team including general zoologists as well as systematists, students of distribution, ecologists, biometricians, and geneticists. I believe that a careful organisation of research in this field would be extremely fruitful. 